\title{
The Effect of Adding Protected Amino Acids in the Rumen (Methionine and Lysine and their Mixtures) on Some Physiological Characteristics of Male Arabi Lambs
}

\author{
Yahya Harbi Abdul-Noor ${ }^{1}$, Amad Falah Hassan ${ }^{* 2}$ \\ 1,2 Animal production Department / College of Agriculture / Basra University / Basra / Iraq
}

*Corresponding Author: amad_falah@yahoo.com

\begin{abstract}
Article history:
Received 14 April 2021

Accepted 19 May 2021
\end{abstract}

keyword: Protected amino acids, methionine, lysine, physiological trails, lambs.

\begin{abstract}
This study was conducted at the animal field of the Agriculture College / University of Basra / Karma Ali site for the period from 7/10/2019 to 1/5/2020 to investigation the effect of adding protected amino acids (methionine and lysine and their mixtures) on some physiological trails of male Arabi lambs. Sixteen male lambs with an average weight of (27.95) $\mathrm{kg}$ and an age of 5-6 months were selected, and randomly divided into four group (4 animals per group). The results indicated that there were no significant differences in the concentration of hemoglobin, packed cell volume, the number of red and white blood cells, cholesterol, triglycerides and the activity of the liver enzyme (ALT and AST) between the different treatments, while there was a significant $(\mathrm{p}<0.05)$ increase in the total protein and albumin concentration in the fourth treatment compared with the first treatment (control), while, there was a significant decrease $(\mathrm{p}<0.05)$ in the urea concentration for the fourth, third and second treatments compared with the first treatment. The concentrations of glucose, thyroxine and growth hormone increased significantly $(\mathrm{p}<0.05)$ in the fourth and second treatment compared with the first treatment. However, it can be concluded from the study that feeding the male lambs with $5 \mathrm{~g}$ methionine or mixing it with lysine by $5 \mathrm{~g}$ raises the concentration of glucose, growth hormones and thyroxine in the blood. Also, the levels of methionine and lysine used did not change the concentration of the studied biochemical parameters.
\end{abstract}

\section{Introduction}

The availability of amino acids in the diet differs depending on the ingredients used in the diets. It is noticed that corn is low in the amino acid lysine, and alfalfa contains few amount of methionine available in the diet (Weiss et al., 2002). The diets with a high content of protein and amino acids, when fed by ruminants, the microorganisms in the rumen degradation most of the protein and amino acids into microbial protein, and this limits the amount of amino acids that cross the rumen and become available to the animal (Koenig et al., 2001). The small intestine absorbed the microbial protein and the non-analyzed protein, and the amino acids are connective together into chains peptides to convert to many forms of proteins, they are used in tissue synthesis as well as their role in many other important functions such as synthesis the hormones, neuro-transferor, and nucleotides of DNA (Schwab et al., 2010). Amino acid play an important role in regulation of the metabolic pathways essential for growth, reproduction, immunity, body weight and milk production in animals, and amino acids can also be used in sugar or fatty acid production (Martínez et al., 2017; Qasim et al., 2019) .The nutritional deficiency deficiencies of amino acids may lead to death of body (Giallongo et al. 2015), and after a period of time production will be negatively affected due to unavailability of amino acids in the diet, and cause negative effects on health and immunity of animal (Giallongo et al., 2016). Ordway et al (2009) indicated that it is may improve the performance of ruminants by supplementing with the protected amino acids, especially methionine and lysine because the 
microorganisms in the rumen rapidly degradation most of the amino acids to ammonia, organic acids and carbon dioxide, so adding methionine supplements Lysine improves diet content. The study of Lee et al (2015) indicated that ammonia emissions from feces were $19 \%$ lower when the diet was supplemented with methionine and lysine compared to $31 \%$. \% when the diet was not supplemented with methionine and lysine, this means that less nitrogen will be released into the environment system. Many methods have been conducted using many physical and chemical treatments to protect amino acids from degradation in the rumen such as treating amino acids with formaldehyde or fat coating and these techniques are called protected protein (transient protein), which are bind with amino acids to provide protection, but this method is costly and non-active, or using the aldehyde compounds such as (formaldehyde) which is one of the important, economical and most widely used in protecting protein and amino acids from degradation in the rumen (Graulet et al., 2005; Hassan, et al., 2011; Shelke et al., 2012). So, this study aimed to find the effect of adding protected amino acids methionine and lysine to ruminant diets and examine their impact on the performance and carcass characteristics of male Arabi lambs. The study aimed to find the effect of different levels of protected amino acids (methionine and lysine) added to lambs' diets on some biochemical and blood parameters, and concentrations of some metabolic hormones.

\section{Materials and Methods}

\section{Ethical Approval}

all applicable national and international guidelines for the care and use of animals were followed.

This study was conducted in the animal field of Agriculture College /Basra University, during the period July 2019 -May 2020. A total of 16 Arabi lambs male were bought from the local farmer, aged between 5-6 months old and $27.88 \mathrm{~kg}$ of body weight were kept in pens (four animals per group), each pens was supplied with a water and food. All the lambs were fed concentrate diet at 7:00 a.m. and 4 p.m daily by (3\%) of the body weight. The protection of the amino acids methionine and lysine was before supplementing to the diet according to the method of Preston and Leng (1985). The ingredients compositions of the diet and the chemical composition as shown in Tables 1 and 2, there was a preparatory period without additions for two weeks (14 days). Later, lambs fed on meals as follows: The first group Without any addition, second group added with $5 \mathrm{~g} / \mathrm{kg}$ feed methionine, third group added with $5 \mathrm{~g} / \mathrm{kg}$ feed lysine and fourth group added with $5 \mathrm{~g}$ methionine $+5 \mathrm{~g}$ lysine $/ \mathrm{kg}$ feed.

\begin{tabular}{|c|c|c|c|c|}
\hline Ingredient & First & Second & Third & Fourth \\
\hline Barley & 61 & 61 & 61 & 61 \\
\hline Bran & 35 & 35 & 35 & 35 \\
\hline Urea & 1 & 1 & 1 & 1 \\
\hline Vitamins and mineral premix & 2 & 2 & 2 & 2 \\
\hline Salt & 1 & 1 & 1 & 1 \\
\hline Methionine* & 0 & 0.5 & 0 & 0.5 \\
\hline Lysine* & 0 & 0 & 0.5 & 0.5 \\
\hline
\end{tabular}

$*(5 \mathrm{~g} / \mathrm{kg}$ feed $)$

Table 2. The Chemical compositions of the diet

\begin{tabular}{|c|c|}
\hline Chemical compositions & $(\%)$ \\
\hline Dry matter & 88.27 \\
\hline Crude protein & 13.98 \\
\hline Ether Extract & 2.80 \\
\hline Crude Fibre 7.68 & 7.47 \\
\hline Nitrogen free extract & 59.95 \\
\hline Organic matter & 84.20 \\
\hline Ash & 4.07 \\
\hline Metabolic energy MJ/kg Dry matter & 11.29 \\
\hline
\end{tabular}


(Al-Khawaja et al, 1978)

Blood samples collection, serum separation and determination of blood parameters (red blood cell count (RBC) and pack cell volumes (PCV)) were measured according to the method as described by Hughes et al (2004). White blood cell (WBC) was measured according to Hean (1995) method. The concentration of hemoglobin $(\mathrm{Hb})$ was measured the method which described by Schalm et al (1975). Total protein, albumin, cholesterol, triglycerides and urea concentration were measured by using a chemical kit of the Biomerieux Company -French. The concentration of glucose was measured by using a chemical the kit analysis produced by Spinreact - company French. Alanine aminotransferase (ALT) and Aspartate transaminase (AST) enzymes were measured by using a chemical kit provide by the Biolabo Company- French. Finally, the concentrations of thyroxin (T4) and Growth hormone were determined by using the kit produced by the Monobind American Company lnc- U.S.A.
The data were analyzed statistically using the complete random design (CRD). And to test the significant differences between the means at a significant level $(\mathrm{p}<0.05)$ used the statistical program version copy 23 SPSS (2015).

\section{Results and Discussion}

Table 3 showed that there were no significant differences in $\mathrm{Hb}$ concentration and PCV between all the groups. The means of $\mathrm{Hb}$ concentrations were $(9.49,9.70,9.51$, and 9.70) $\mathrm{g} / \mathrm{dL}$, respectively, while the means of PCV were (28.53, 30.30, 28.87 and $30.54 \%$ ), respectively. In similar studies on buffalo, did not recorded significant differences in $\mathrm{Hb}$ concentrations and PCV when they added the protected amino acids to their diets (Giallongo et al, 2016; Rajwade, 2019). While, It is different from Shaawi (2017) that recorded a significant increase in $\mathrm{Hb}$ concentration in Awassi lambs when a mixture of unprotected amino acids methionine + lysine at dosed $(5+5) \mathrm{g} /$ animal / day compared to the control group

Table 3. The effect of adding protected amino acids on concentration hemoglobin and packed cell volume (Mean $\pm S$.

\begin{tabular}{|c|c|c|}
\hline Groups & $\mathrm{Hb}(\mathrm{g} / \mathrm{dL})$ & $\mathrm{PCV}(\%)$ \\
\hline Control (1st) & $9.49 \pm 0.32$ & $28.53 \pm 1.11$ \\
\hline $5 \mathrm{~g}$ methionine kg/feed (2nd) & $9.70 \pm 0.57$ & $30.30 \pm 0.76$ \\
\hline $5 \mathrm{~g}$ lysine kg/diet (3rd) & $9.51 \pm 0.83$ & $28.87 \pm 1.56$ \\
\hline 5g methionine + 5g lysine kg/ feed (4th) & $9.70 \pm 0.60$ & $30.54 \pm 1.08$ \\
\hline Significant & N.S & N.S \\
\hline
\end{tabular}

Table 4 shows that there were no significant differences in the total number of RBC and WBC between the all groups. The means of these parameters for the four groups were $(4.78,5.05$, $4.94,5.02) \times 103$ and $(6.31,5.56,5.75,5.77) \times 103$ respectively. Shaawi (2017) obtained similar results, that there were no significant differences in the numbers of red blood cells and white blood cells when fed Awassi lambs unprotected amino acids methionine and lysine compared with the control group. The protected amino acid methionine at (15) $\mathrm{g}$ / animal / day in calves' feeding, as they found no significant differences in the red blood cell counts compared with the control group, and, the results of Movaliya et al (2013), when they added the protected amino acids methionine and lysine $(5,10)$ $\mathrm{g} /$ animal / day to the diets of buffalo calves, no significant differences were observed in the numbers of RBC and WBC compared to the control group.

Table 4. The effect of adding protected amino acids on numbers of red blood cells and white blood cells (Mean \pm S. E.)

\begin{tabular}{|c|c|c|}
\hline Groups & RBC $\times 10^{3} / \mathrm{L}$ & $\mathrm{WBC} \times 10^{6} / \mathrm{L}$ \\
\hline Control (1st) & $4.78 \pm 2.28$ & $6.31 \pm 0.30$ \\
\hline $5 \mathrm{~g}$ methionine kg/ feed (2nd) & $5.05 \pm 0.23$ & $5.56 \pm 0.20$ \\
\hline $5 \mathrm{~g}$ lysine $\mathrm{kg} / \mathrm{feed}$ (3rd) & $4.94 \pm 0.30$ & $5.75 \pm 0.26$ \\
\hline $\begin{array}{c}5 \mathrm{~g} \text { methionine }+5 \mathrm{~g} \text { lysine kg/ } \\
\text { feed (4th) }\end{array}$ & $5.02 \pm 0.35$ & $5.77 \pm 0.41$ \\
\hline Significant & N.S & N.S \\
\hline
\end{tabular}


Table 5 shows the total protein concentration in the serum of lambs of the four groups during the study period. No significant differences were observed in the total protein concentration between the groups of the study, as, the means recorded $(6.71,6.40$, $6.22,5.85) \mathrm{g} / 100 \mathrm{ml}$ to the fourth, third, second and first groups respectively. While the fourth treatment recorded a significant $(p<0.05)$ increase in the total protein concentration at the end of the study period (the third month) compared to the control group. This result was in agreement with the result of Li et al, (2019) when they used protected methionine $(3,4.5) \mathrm{g} /$ head / day in feeding male lambs of Ningxia Tan breed for 60 days, where they obtained a significant increase in the total protein concentration compared to the control group, and this may be explained by the fact that the protection protein reduces the degree of degradation it in the rumen and increases its reach to the stomach and small intestine, which an increase in the absorption of amino acids and thus increase the protein in the serum (Richardel, 2004; Ali e al., 2005). Kandil et al., (2017) reported an increase in the total protein concentration in serum as a result of methionine supplementation. Other studies did not obtain significant differences such as Imik and Gunlu (2011) when using the protected methionine at $2 \mathrm{~g}$ $/ \mathrm{kg}$ of diet in Morkaraman breed compared with the control group.

Table 5. The effect of adding protected amino acids on concentration of total protein $(\mathrm{g} / 100 \mathrm{ml})$ in serum of lambs during the experimental periods (Mean \pm S. E.)

\begin{tabular}{|c|c|c|c|c|}
\hline Adjective & First Mo. & Second Mo. & Third Mo. & Overall mean \\
\hline Groups & $0.92 \pm 5.72$ & $.69 \pm 06.23$ & $.56 \pm 05.60^{\mathrm{b}}$ & $.19 \pm 05.85$ \\
\hline Control (1st) & $0.63 \pm 5.55$ & $1.01 \pm 6.29$ & $.40 \pm 06.84^{\text {ab }}$ & $0.37 \pm 6.22$ \\
\hline $5 \mathrm{~g}$ lysine $\mathrm{kg} / \mathrm{feed}(3 \mathrm{rd})$ & $.70 \pm 06.18$ & $0.96 \pm 6.65$ & $.75 \pm 06.39^{\mathrm{ab}}$ & $.13 \pm 06.40$ \\
\hline $\begin{array}{c}\text { 5g methionine + 5g lysine kg/ } \\
\text { feed (4th) }\end{array}$ & $.96 \pm 05.84$ & $.83 \pm 06.76$ & $.25 \pm 07.53^{\mathrm{a}}$ & $.48 \pm 06.71$ \\
\hline Significant & N.S & N.S & $\left(^{*}\right)$ & N.S \\
\hline
\end{tabular}

Different small letter within column means significant difference $\left(^{*}\right)(p<0.05)$ between groups.

Table (6) shows that there are significant differences $(\mathrm{p}<0.05)$ in the concentration of albumin in the fourth group, which recorded (3.81) $\mathrm{g} / 100 \mathrm{ml}$ compared with the control group, reaching (3.20) g/ $100 \mathrm{ml}$, may be due to increasing the absorption of the true protein in the small intestine when feeding the protected protein $(\mathrm{Oh}$ et al, 2008), and this is similar to the results of Gavade et a., (2019), that confirmed that a significant difference was obtained in albumin concentration when feeding calves on a mixture of the protected amino acids methionine and lysine $(3+20 \mathrm{~g} /$ animal / day) when compared with the control group, whereas, it is different from the results of Elwakeel et a., (2018), which did not record significant differences in the albumin concentration compared to the control group when they added the protected amino acid lysine at (3) g / animal / day to the diets of lambs of the Egyptian Barqi breed. A significant $(p<0.05)$ increase was observed in glucose concentration in the fourth and second groups, reaching $(69.11,68.43) \mathrm{mg} / 100 \mathrm{ml}$, respectively, compared to the control group, reaching (43.85) $\mathrm{mg} / 100 \mathrm{ml}$, and the reason may be due to the metabolism of the amino acid methionine in the liver and its association with an increase in glucose concentration (Ganong, 2005;
Sun et a., 2016) . These results are consistent with the results of Li et al. (2019) when methionine was administered as protected amino acid at levels of $(0$, $1.5,3,4.5,6) \mathrm{g} /$ head / day for 60 days in the diet of lambs. And similar to the results of Qasim et al (2019) when feeding Awassi ewes on a mixture of the protected amino acid methionine + lysine at a rate of $(2.5+2.5) \mathrm{g} /$ animal / day. But, it did not agree with the results of Imik and Gunlu (2011) when adding methionine amino acid at $2 \mathrm{~g} / \mathrm{kg}$ to the diets of lambs of Morkaraman breed. The concentration of urea was a significant $(\mathrm{P}<0.05)$ decrease in fourth, third and second groups and it reached $(2.95,3.28,3.16) \mathrm{mmol} / \mathrm{L}$, respectively, compared with the control group (4.34) mmol / liter. The reduced level of urea in the serum may be due to the absorption and deposition protein into the tissues and the reduction in the catabolism of amino acids, which led to a decrease in serum urea (Hussein et al., 2016; Rajwade et al., 2019) .These results are in agreement with Tsiplakou et al (2018) and Singh et al (2015). But, it did not agree with the results of Younis and Abd-Elazem (2019) when they used the protected amino acids methionine and lysine at (7, 3) g / animal / day, respectively, in feeding ewes. The reason of the between the studies 
effect may be due to the method of addition, physiological condition, age, and animal type.

Table 6. The effect of adding protected amino acids on albumin, Glucose and Urea concentrations in serum of lambs (Mean \pm S. E.)

\begin{tabular}{|c|c|c|c|}
\hline Groups & Albumin $(\mathrm{g} / 100 \mathrm{ml})$ & Glucose $(\mathrm{mg} / \mathrm{ml})$ & urea $(\mathrm{mmol} / \mathrm{L})$ \\
\hline${\text { Control }\left(1^{\mathrm{st}}\right)}^{\mathrm{a}}$ & $3.20^{\mathrm{b}} \pm 0.16$ & $43.85^{\mathrm{b}} \pm 5.79$ & $4.34^{\mathrm{a}} \pm 0.16$ \\
\hline $5 \mathrm{~g}$ methionine $\mathrm{kg} /$ feed $\left(2^{\text {nd }}\right)$ & $3.37^{\mathrm{ab}} \pm 0.11$ & $68.43^{\mathrm{a}} \pm 8.07$ & $3.16^{\mathrm{b}} \pm 0.36$ \\
\hline $5 \mathrm{~g}$ lysine $\mathrm{kg} /$ feed $(3 \mathrm{rd})$ & $3.52^{\mathrm{ab}} \pm 0.08$ & $54.22^{\mathrm{ab}} \pm 3.71$ & $3.28^{\mathrm{b}} \pm 0.25$ \\
\hline $\begin{array}{c}5 \mathrm{~g} \text { methionine }+5 \mathrm{~g} \text { lysine } \\
\mathrm{kg} / \text { feed }\left(4^{\text {th }}\right)\end{array}$ & $3.81^{\mathrm{a}} \pm 0.18$ & $69.11^{\mathrm{a}} \pm 9.80$ & $2.95^{\mathrm{b}} \pm 0.36$ \\
\hline Significant & $\left(^{*}\right)$ & $\left(^{*}\right)$ & $\left(^{*}\right)$ \\
\hline
\end{tabular}

Different small letter within class means significant difference $\left(^{*}\right)(\mathrm{p}<0.05)$ between groups

Table (7) shows that there were no significant differences in the cholesterol concentration and triglycerides and the activity of the liver enzyme ALT and AST between all groups. The means of cholesterol, triglyceride, ALT and AST concentration were $(87.00,76.28,85.40,88.52) \mathrm{mg}$ / $100 \mathrm{ml}$, and $(63.49,57.98,60.11,62.99) \mathrm{mg} / 100$ $\mathrm{mL}$ and $\mathrm{ALT}(14.64,15.51,16.91,14.84) \mathrm{IU} / \mathrm{L}$, AST $(40.71,42.22,43.37,41.33)$ IU / L, respectively. The results were in agreement with the results of Mousavi et al (2016) and Elwakeel et al (2018) when adding amino acids (methionine and lysine) to the diets of Iranian ewes and lambs of the Egyptian Barqi breed, which they did not recorded significant differences in the concentration of triglyceride and cholesterol. Whereas, it did not agree with the results of Rodriguez-Guerrero et al (2018) when using protected methionine amino acid, which reported significant differences in cholesterol and triglyceride concentrations. The results of this study showed that the concentration of the liver enzyme AST in the serum was within the normal range (40-110 IU / L) (Dokovic et al., 2010), Our results about enzymes were similar to those for Sun et al (2016) and Younis, and AbdElazem, (2019) when adding the protected amino acids (methionine and lysine) to the diets of cows and ewes.

Table 7. The effect of adding protected amino acids on Cholesterol, Triglycerides, AST and ALT

\begin{tabular}{|c|c|c|c|c|}
\hline Groups & $\begin{array}{c}\text { Cholesterol } \\
(\mathrm{g} / 100 \mathrm{ml})\end{array}$ & $\begin{array}{c}\text { Triglycerides } \\
(\mathrm{g} / 100 \mathrm{ml})\end{array}$ & AST ( IU / L) & ALT ( IU / L) \\
\hline $\begin{array}{c}\text { Control (1st) } \\
\begin{array}{c}5 \mathrm{~g} \text { methionine kg/feed } \\
(2 \mathrm{nd})\end{array}\end{array}$ & $87.00 \pm 14.45$ & $63.49 \pm 7.20$ & $40.71 \pm 0.50$ & $14.64 \pm 0.19$ \\
\hline $\begin{array}{c}5 \mathrm{~g} \text { lysine kg/feed (3rd) } \\
\begin{array}{c}5 \mathrm{~g} \text { methionine }+5 \mathrm{~g} \text { lysine } \\
\mathrm{kg} / \mathrm{feed}(4 \mathrm{th})\end{array}\end{array}$ & $85.40 \pm 1.37$ & $60.11 \pm 7.01$ & $43.37 \pm 1.62$ & $16.91 \pm 1.56$ \\
\hline Significant & N.S & $62.99 \pm 8.03$ & $41.33 \pm 0.89$ & $14.84 \pm 0.18$ \\
\hline
\end{tabular}

The data in Table 8 indicated that was significant $(\mathrm{P}<0.05)$ increase in the concentration of the thyroxine hormone in fourth and second groups $(19.62,18.35) \mathrm{ng} / \mathrm{ml}$ respectively, compared with the third and first groups $(16.90,15.25) \mathrm{ng} / \mathrm{ml}$ respectively. The improvement of thyroid hormone secretion (thyroxine) may be due to increasing of carbohydrate, fat and protein metabolism, and the positive effect on the digestibility of these compounds and the positive relationship between energy intake and the concentration of thyroid hormones (Ahmed, 2003; Abdel-Ghani et al, 2011). Also, amino acids play a crucial role in the synthesis of thyroid hormones related to metabolic processes that have a direct effect on improving the growth and development of animals (Ana-Maria et al, 2009). Our results are similar to the results of the study Kassim et al (2019) when using a mixture of amino acids at a dose $(10,20) \mathrm{g} / \mathrm{head} /$ day on Arabi lambs. It also shows a significant $(\mathrm{P}<0.05)$ 
increase in the concentration of growth hormone in the second, third and fourth groups. The values were $(9.83,8,45$ and 8.76$) \mathrm{ng} / \mathrm{ml}$ respectively, compared with the first group $(6.72 \mathrm{ng} / \mathrm{ml})$. The reason for the rise of the growth hormone concentration of the treatments may be due to the strong relationship between the availability of amino acids and the concentration of growth hormone because it is one of the protein hormones, and when the availability of balanced amino acids in the diet will cause increase in the concentration of growth hormone.

Table 8. The effect of adding protected amino acids on concentration Thyroxin hormone (T4) and growth hormone $(\mathrm{GH})(\mathrm{ng} / \mathrm{ml})$ in serum of lambs (Mean \pm S. E.)

\begin{tabular}{|l|c|c|}
\hline \multicolumn{1}{|c|}{ Groups } & $\begin{array}{c}\text { Thyroxin } \\
\text { hormone }\end{array}$ & growth hormone \\
\hline Control (1st) & $15.25^{\mathrm{b}} \pm 0.69$ & $6.72^{\mathrm{c}} \pm 0.22$ \\
\hline $5 \mathrm{~g}$ methionine kg/feed (2nd) & $18.35^{\mathrm{a}} \pm 0.91$ & $9.83^{\mathrm{a}} \pm 0.24$ \\
\hline $5 \mathrm{~g}$ lysine $\mathrm{kg} / \mathrm{feed}(3 \mathrm{rd})$ & $16.90^{\mathrm{b}} \pm 0.34$ & $8.45^{\mathrm{b}} \pm 0.26$ \\
\hline $5 \mathrm{~g}$ methionine $+5 \mathrm{~g}$ lysine $\mathrm{kg} /$ feed $(4 \mathrm{th})$ & $19.52^{\mathrm{a}} \pm 1.52$ & $8.76^{\mathrm{b}} \pm 0.10$ \\
\hline Significant & $\left(^{*}\right)$ & $\left(^{*}\right)$ \\
\hline
\end{tabular}

Different small letter within class means significant difference $(*)(\mathrm{p}<0.05)$ between groups

\section{Conclusions}

From our data, it could be suggested that the protected amino acids methionine and lysine and at a dose $5 \mathrm{~g} / \mathrm{kg}$ of feed do not change the normal levels of blood picture such as hemoglobin, PCV, $\mathrm{RBC}$ and $\mathrm{WBC}$ or on some metabolic parameters such as total protein, cholesterol and triglycerides. However, the combination of these two acids improves the concentration of albumin and glucose levels and decrease serum urea concentration of lambs. In addition, the two acid levels which used in the our study did not cause stress in the animals because they did not effect on the liver enzymes such as ALT and AST.

\section{Conflict of Interest}

Authors declare that they have no conflict of interest.

\section{Acknowledgements}

We would like to thank the Deanship of Agriculture College - University of Basra for their moral assistance in completing the study. We also thank the physiological laboratory manager in the Animal Production Department for his help in the laboratory analyzes.

\section{References}

Abdel-Ghani, A. A., G. A. Solouma, A. Y. Kassab and E. B. Soliman. 2011. Productive performance and blood metabolites as affected by protected protein in sheep. Open J. Anim. Sci., 1: 24-32.

Ahmed, S.K.S. 2003. Studies on energy and protein allowances in ration for pregnant and milk producing buffaloes. Ph.D. Thesis, Faculty of Agriculture, Ain Shams University, Cairo.

Ali, M. F., B. E. El-Saidy, M. L. Bassiouni, M. K. Mohsen, and M. M. E. Khalalfalla. 2005. Performance of lambs fed on rations containing soybean meal treated with formaldehyde and probiotics. 1l-Productive and reproductive performance. Egyptian J. Nutrition and Feeds., 8: 511-527.

Al-Khawaja, A. K., E. Abdullah and S. Abdul Ahad. 1978. The chemical composition and nutritional value of Iraqi feed materials. Bulletin issued by the Nutrition Department, Directorate of Animal Resources, Iraqi Ministry of Agriculture and Reform, Iraq.

Ana-Maria, S., B. Victor and M. Barbara. 2009. New trends in Classification ,Diagnosis and Management of Thyroid Diseases. The 9th efcc Continuous Postgraduate Course in Clinical Chemistry Under The Auspices of ifcc. Handbook, Dubrovnik.m pp 1-118.

Dokovic, R., Z. Ilic, V. Kurcubic, V. Doskovic and B. Jašovic. 2010. Blood biochemical parameters and enzyme activity in beef cattle. Acta Agriculturae Serbica. 29: 47-54 .

Elwakeel, E. A., H. M. El-Zaiat and A. S. Morsy. 2018. effect of rumen-protected lysine (hydroxy methyl lysine) supplementation on performance 
and blood metabolites in Barki sheep. Egyptian Journal of Nutrition and Feeds, 21: 645-654.

Ganong, W.F. 2005. Review of Medical and Physiology. 22nd ed. New York: McGraw-Hill Companies.

Gavade, V., G. Gadegaonkar, B. Ramteke, S. Jagadale and A. Pagdhune. 2019. Effect of supplementation of rumen protected methionine and lysine in crossbred calves. Inter. J. .Livestock Res., 9: 182-188

Giallongo, F., A. N. Histrov, J. Oh, T. Frederick, H. Weeks, J. Werner, H. Lapierre, R. A. Patton, A. Gehman and C. Parys. 2015. Effects of slow-release urea and rumen-protected methionine and histidine on performance of dairy cows. J. Dairy Sci., 98:3292-3308.

Giallongo, F., M. T. Harper, J. Oh, J. C. Lopes, H. Lapierre, R. A. Patton, C. Parys, I. Shinzato and A. N. Hristov. 2016. Effects of rumen-protected methionine, lysine, and histidine on lactation performance of dairy cows. J. Dairy Sci. 99:44374452.

Girard, C. L., H. Lapierre, J. J. Matte and G. E. Lobley. 2005. Effects of dietary supplements of folic acid and rumen-protected methionine on locational performance and folate metabolism of dairy cows. J. Dairy Sci., 88:660-670.

Hassan, S., A. R. Ahmed, W. Al-Samaraae and A. B. Ali. 2011. Effects of rumen protected arginine supplementation on growth rate, rumen fermentation and blood biochemical of Awassi lambs. KSÜ. Doğa . Bilimleri Dergisi., 14: 38-45. Hean , P. J. 1995. Principle of Hematology. Edited by: L. H. Yong. ; W. B. Publishers. London.

Hughes, N. C., S. N. Wickramasinghe and C. Hatton. 2004. Lecture Notes on Hematology. Seventh Edition. Blackwell Publishing. London. Hussein, A. H., E. D. Batista, M. D. Miesner and E. C. Titgemeyer. 2016. Effect of ruminal ammonia supply on lysine utilization by growing steers. J. Anim. Sci., 94: 656-664.

Imik, H., and A. Gunlu. 2011. Effects of sodium bicarbonate, polyethylene glycol and methionine added to rations with sorghum (Sorghum vulgare) in fattening lambs on growth performance, wool quality and some blood biochemical markers. J. Rev .Med. Vet., 162: 432-439.

Kandil, A. M., M. A. Boraei, M. A. I. El-Sysy and A. S. Abdeltawab. 2017. Effect of protected methionine supplementation on productive performance of growing buffalo calves. Egyptian J. Nutrition and Feeds. 20:163-173.

Kassim, W. Y., F. A. Al-Asadi, and B. S. Mohsen. 2019. Effect of treatment with a mixture of amino acids at different levels on some biochemical parameters and wool, carcass characterizes in the
Arabi lambs breed. Adv. Anim. Vet. Sci., 7: 383388.

Koenig, K. M. and L. M. Rode. 2001. Ruminal degradability, intestinal disappearance, and plasma methionine response of rumen-protected methionine in dairy cows. J. Dairy Sci., 84:14801487.

Lee, C., F. Giallongo, A. N. Hristov, H. Lapierre, T. W. Cassidy, K. S. Heyler, G. A. Varga and W. Parys. 2015. Effect of dietary protein level and rumen-protected amino acid supplementation on amino acid utilization for milk protein in lactating dairy cows. J. Dairy Sci., 98:1885-1902.

Li, H., B. Jiang and Y. Zhou. 2019. Effects of supplementation of rumen-protected methionine on performance, nitrogen balance, carcass characteristics and meat quality of lambs fed diets containing buckwheat straw. Canad. J. Anim. Sci.,100: 337-345.

Martínez, Y., X. Li, G. Liu, P. Bin, W. Yan, D. Más and Y. Yin. 2017. The role of methionine on metabolism, oxidative stress, and diseases. Amino Acids.,49: 2091-2098.

Mousavi, S., N. Amanloo, T. Mostafa and A. Mirzaei. 2016. Effect of reduced metabolizable protein supplemented with rumen protected lysine and methionine on performance of pregnant Afshari ewes. Iran .Anim. Sci., 47 : 89-102 .

Movaliya, J. K., K. S. Dutta, R. J. Padodara, A. R. Bhadaniya and H. H. Savsani. 2013. Effect of bypass methionine-lysine supplementation on hematological and blood biochemical parameters of Jaffarabadi heifers. Vet .World., 6: 147-150.

Oh, Y., J. Kim, K. Kim, C. Choi, S. Kang, I. Nam, D. Kim, M. Song, C. Kim and K. Park. 2008. Effects of level and degradability of dietary protein on ruminal fermentation and concentrations of soluble non-ammonia nitrogen in ruminal and omasal digesta of hanwoo steers. Asian-Aust. J. Anim. Sci., 21: 392-403

Ordway, R. S., S. E. Boucher, N. L. Whitehouse, C. G. Schwab and B. K. Sloan. 2009. Effects of providing two forms of supplemental methionine to per-parturient Holstein dairy cows on feed intake and locational performance. J. Dairy Sci., 92:51545166.

Preston, T. R. and R. A. Leng. 1985. Assay for bypass protein in a supplement . In : Matching livestock systems to available feed resources. ILCA . Addis ababa . pp . 196-197.

Qasim, H. W. Q., O. D. Muhammad and S. Y. A. Rahman. 2019. The effect of adding methionine and protected lysine to the Awassi ewes diet during the feeding period on reproductive performance. Iraqi Journal of Veterinary Sciences. Volume 33: 105109. 
Rajwade, N. 2019. Effect of dietary supplementation of rumen protected methionine and lysine on haematological and blood biochemical profile in sahiwal female calves. Intern.J. Agric. Sci., 11: 8322-8324.

Richardel, P.T. 2004. Effects of dietary protein level and fish meal on growth and hormonal status of weaned dairy calves. MSc . Thesis, Louisiana State University and Agricultural and Mechanical College.

Rodriguez-Guerrero, V., A. C. Lizarazo, S. Ferraro, N. Suárez, L. A., Miranda and G. D. Mendoza. 2018. Effect of herbal choline and rumen-protected methionine on lamb performance and blood metabolites. South Afr. J. Anim . Sci., 48: 427-434. Schalm, O. W., N.C. Jain and E. J. Carrol. 1975. Veterinary Haematology. 3rd (ed.) Lea and Febiger. Philadelphia, U.S.A.

Schwab, C. G. 2010. Balancing Diets for Amino Acids: Nutritional, Environmental and Financial Implications. In Proceedings of the 19th Annual Tri-State Dairy Nutrition Conference, Grand Wayne Center, Fort Wayne, Indiana, USA, 20-21 April, 2010 (pp. 1-13). Purdue University Press..

Shaawi, S. M. E. 2017. Effect of methionine and lysine dosing of orphan lambs on growth rates, rumen fluid characteristics, and some biochemical and physical blood characteristics. Tikrit Journal of Agricultural Sciences. Volume 17: 123-118

Shelke, S. K., Thakur, S. S. and Amrutkar, S. A. 2012. Effect of feeding protected fat and proteins on milk production, composition and nutrient utilization in Murrah buffaloes (Bubalus bubalis). Anim. Feed Sci. Tech., 171: 98- 107.

Singh, J. K., D. Roy, V. Kumar, M. Kumar and R. Sirohi. 2015.Effect of supplementing rumen protected methionine and lysine on nutrient utilization, growth and blood biochemical parameters in Hariana heifers. Indian. J. Anim. Nutr., 32:187-191.

SPSS, Statistical Package for the Social Sciences. 2015. Quantitative data analysis with IBM SPSS version 23: A Guide for Social Scientists. New York: Routledge.

Sun, F., Y. Cao, C. Cai, S. Li, C. Yu and J. Yao. 2016. Regulation of nutritional metabolism in transition dairy cows: energy homeostasis and health in response to post-ruminal choline and methionine. Plos one.11: 1-27.

Tsiplakou, E., A. Mavrommatis, D. Skliros, K. Sotirakoglou, E. Flemetakis, and G. Zervas. 2018. The effects of dietary supplementation with rumenprotected amino acids on the expression of several genes involved in the immune system of dairy sheep. J. Anim. Physic. and Anim. Nutr., 102: 1437-1449.
Weiss, W.P. 2002. Protein and carbohydrate utilization by lactating dairy cows. North Carolina Dairy Nutrition Management Conference. P. 44. Younis, F. E. and R. A. Abd-Elazem. 2019. Effect of supplementation of rumen-protected amino acids to Barki sheep on some blood parameters. Inter. J. Enviro . Agric. Bio.,4:1549-1553. 